\title{
Perception of Family Functioning Among Relatives of Women Who Survived Breast Cancer: Gender Differences
}

\author{
Raquel Gabrielli Biffi' \\ Marli Vilela Mamede ${ }^{2}$
}

The aim of this study was to know how female and male family members perceive their family dynamics after breast cancer. Barnhill's proposal of a healthy family functional model served as the theoretical framework for this qualitative research. The data was obtained through interviews and submitted to content analysis. The results showed that, in the adaptation process to breast cancer, both genders use clear communication in order to achieve family balance and present interactions characterized by mutual and individual feelings. The responsibility for maintaining the family is attributed to the daughters, whereas the male elements show more disorganization with regard to family functions. The bond between family members of both genders who are affected by breast cancer shows important interactions in the identity process.

Descriptors: Breast Neoplasms; Family; Gender Identity; Nursing.

\footnotetext{
${ }^{1}$ Ph.D. in Nursing, Faculty, Departamento de Enfermagem, Centro Universitário Barão de Mauá, SP, Brazil. E-mail: gabriellibiffi@ yahoo.com.br.

2 Ph.D. in Nursing, Full Professor, Escola de Enfermagem de Ribeirão Preto, Universidade de São Paulo, WHO Collaborating Centre for Nursing Research Development, SP, Brazil. E-mail: mavima@eerp.usp.br.
}

Corresponding Author:

Centro Universitário Barão de Mauá

Rua Ramos de Azevedo, 423

Jardim Paulista

CEP: 14050-090 Ribeirão Preto, SP, Brasil

E-mail: gabriellibiffi@yahoo.com.br 


\title{
Percepção do funcionamento familiar entre familiares de mulheres sobreviventes ao câncer de mama: diferenças de gênero
}

O objetivo deste estudo foi conhecer como familiares do gênero feminino e masculino percebem a dinâmica de suas famílias, após o câncer de mama. Investigação de abordagem qualitativa que tomou como referencial teórico o modelo de funcionamento familiar saudável, proposto por Barnhill. Participaram 23 familiares constituintes de 10 famílias. Os dados foram coletados por meio de entrevistas e submetidos à análise de conteúdo. Os resultados mostraram que, no processo de adaptação ao câncer de mama, ambos os gêneros utilizam a comunicação clara para a busca do equilíbrio familiar e apresentam interações caracterizadas por sentimentos de mutualidade e individuação. Às filhas é atribuída a responsabilidade pela manutenção da família e os elementos do gênero masculino demonstram maior desorganização no funcionamento familiar. 0 vínculo dos familiares de ambos os gêneros que vivenciam o câncer de mama apresentam interações importantes no processo de identidade.

Descritores: Neoplasias da Mama; Família; Identidade de Gênero; Enfermagem.

\section{Percepción del funcionamiento familiar entre familiares de mujeres sobrevivientes de cáncer de mama: diferencias de género}

\begin{abstract}
El objetivo de este estudio fue conocer como familiares del género femenino y masculino perciben la dinámica de sus familias, después del cáncer de mama. Es una investigación de abordaje cualitativo que tomó como marco teórico el modelo de funcionamiento familiar saludable, propuesto por Barnhill. Participaron 23 familiares constituyentes de 10 familias. Los datos fueron recolectados por medio de entrevistas y sometidos al análisis de contenido. Los resultados mostraron que, en el proceso de adaptación al cáncer de mama, ambos géneros utilizan la comunicación clara para la búsqueda del equilibrio familiar y presentan interacciones caracterizadas por sentimientos de mutualidad e individuación. A las hijas es atribuida la responsabilidad por la manutención de la familia y los elementos del género masculino demuestran mayor desorganización en el funcionamiento familiar. El vínculo de los familiares de ambos géneros, que experimentan el cáncer de mama, presenta interacciones importantes en el proceso de identidad.
\end{abstract}

Descriptores: Neoplasias de la Mama; Familia; Identidad de Género; Enfermería.

\section{Introduction}

The confirmation of a breast cancer diagnosis confronts women and their families with difficult decisions and coping experiences. This disease turns into a great challenge in a family's life, as none of its members remains untouched, sometimes causing changes in the configurations established among them, which imposes an important challenge on the family group's ability to remain relatively organized while adapting to the different needs ${ }^{(1)}$.

Health professionals should be sensitized to the extent of recognizing the family as a complex phenomenon that needs support, mainly in breast cancer situations, as these demand significant changes in family dynamics. Family-centered care involves all of its members and special importance is given to the relations established among them, considered as one of the determinants of the health/disease process(2). Clarifications on the disease and the type of treatment to be followed favor health promotion, making patients more independent to take care of themselves and perform other activities related to the environment and the family(3).

Difficulties with regard to the establishment of 
conducts and behaviors that promote family balance are commonly observed in the family unit, revealing that the family needs to pay attention in order to identify conflicting situations, which its members may expose so as to avoid the emergence of irreparable disagreements in the future ${ }^{(4)}$.

A study appoints that, when a member of the family group is affected by breast cancer, the family dynamics changes. And professional experience has shown that relatives' participation in and adjustment to the new family health condition, due to the presence of breast cancer in one of its members, occur differently between that family's male and female gender ${ }^{(5)}$. Experience has also shown that, in this family adaptation process to the new health conditions, a strict division of sexual role among its members coexists, with the female gender often carrying the greatest burden of responsibility for maintaining family harmony.

Literature about the relations between family adjustment after breast cancer and relatives' participation according to gender is quite scarce. In that sense, bringing the gender perspective into research on the family dynamics of relatives with breast cancer permits concrete knowledge development about women's position in that reality and a picture of equality and difference relations between genders in family functioning, considering that the male and female gender occupy different positions and play different roles in the family's care process.

In this research, the gender concept will be considered as the process through which society classifies and attributes values and standards to men and women, thus constructing sexual differences and hierarchies, delimiting male and female roles. Thus, the interpretation of gender differences can point towards a relation of complementariness or hierarchy, depending on the culture(6).

Incorporating the family in the care unit for women with breast cancer is therefore necessary and urgent, and focusing care on social gender relations established between relatives in the adaptation process to the new family living conditions can be an important care strategy. Thus, this research is guided by the following question: is the family dynamics among relatives of women who survived breast cancer distinct between the male and female gender?

The results of this study can provide nurses with a more critical viewpoint on the relation between the family adjustment of women who survived breast cancer and broader issues, in which its members, men and women, model the development of social roles in function of social, sexual and cultural determinants.

\section{Purpose}

To find out how female and male relatives perceive their family dynamics after breast cancer.

\section{Method}

This qualitative research used the healthy family functioning model as its theoretical framework ${ }^{(7)}$. This model of family dynamics is based on the systems theory approach and comprises eight bipolar dimensions grouped in four basic family processes. In the table below, the processes and meanings of each of the dimensions of the healthy family system theory are described(7).

Table 1 - Description of eight basic dimensions of healthy family functioning

\begin{tabular}{|c|c|c|}
\hline \multirow[t]{8}{*}{ Processes of identity } & Individuation & Enmeshment \\
\hline & Refers to independence of thought, feelings & Refers to poorly delineated boundaries of self, to an \\
\hline & and judgments of family members. Identity and & identity dependent on others, to symbiosis, and to \\
\hline & boundaries of the self & shared ego fusion \\
\hline & Mutuality & Isolation \\
\hline & Sense of emotional closeness, intimacy, only & Alienation or disengagement from others \\
\hline & possible between individuals with clearly & \\
\hline & defined identities & \\
\hline \multirow[t]{7}{*}{ Processes of adaptation to change } & Flexibility & Rigidity \\
\hline & Capacity to be adjustable and resilient in & Lack of flexibility, inappropriate and unsuccessful \\
\hline & response to varied conditions and to the & responsiveness to varying circumstances that is \\
\hline & process of change & stereotyped and repetitive \\
\hline & Stability & Disorganization \\
\hline & Consistency, responsibility and security in & Lack of stability or consistency in family relations \\
\hline & family interactions & \\
\hline
\end{tabular}


Table 1 - Continution

\begin{tabular}{|c|c|c|}
\hline \multirow{4}{*}{$\begin{array}{l}\text { Processes of information and } \\
\text { communication }\end{array}$} & Clear communication & Distorted communication \\
\hline & $\begin{array}{l}\text { Clear and successful exchange of information } \\
\text { between family members }\end{array}$ & Vague or confusing exchanges of information \\
\hline & Clear perception & Unclear perception \\
\hline & Undistorted awareness of self and others & Perceptions distorted for another \\
\hline \multirow[t]{5}{*}{ Processes related to role structuring } & Role reciprocity & Role conflict \\
\hline & Mutually agreed upon behavior patterns or & Lack of clearly agreed upon behavioral \\
\hline & $\begin{array}{l}\text { sequences in which an individual complements } \\
\text { the role of a role partner }\end{array}$ & complementariness between family members \\
\hline & Clear generational boundaries & Diffuse or breached generational boundaries \\
\hline & Role reciprocity among family members & Lack of clarity in generational boundaries \\
\hline
\end{tabular}

The positively ordered definitions describe family health and wellbeing and serve as resources in situations in which the family needs to adapt to the new condition. The negatively ordered statements express the need to deal with these situations. The dimensions related to clear and unclear or distorted perception were not used in this research due to the belief that they function as a prerequisite to identify the quality of communication among family members.

\section{Sample}

The sample consisted of 23 family members, represented by ten families of women with breast cancer, who participated in a group specialized in the rehabilitation of women with breast cancer in the interior of São Paulo State, and who were willing to invite their relatives to participate in the research.

Participants were as follows: 11 women (nine daughters, one aunt and one niece) and 12 men (five sons and seven partners). The sample size was concluded when the relatives' statements were organized and analyzed and information shared with the researchers became repetitive.

Initially, all relatives were willing to participate in the research, although one family member refused to participate, alleging insufficient time and not having any problem with breast cancer in the family context, so that this person could not be included in the research.

The relatives were included in the research if they complied with the following criteria: relative of a woman with breast cancer for at least three months; living in the city of Ribeirão Preto or nearby, at a distance of up to fifty kilometers; living at the woman's house, and being over 18 years of age.

\section{Data collection instruments}

A semi-structured interview script was used, containing previously elaborated open questions, which guided towards the understanding of the family's functioning after breast cancer, as follows: what is it like to live with someone in the family who has breast cancer? What has changed in your home? What has changed in your daily life after the surgery to remove the breast cancer? Do you see yourself as someone who gives support? Why? Do or did you have difficulties to deal with the breast cancer diagnosis? Did you talk about this? What have you done/did you do to overcome those difficulties? Who suffered least because of the breast cancer diagnosis? And who suffered most? Who gives most support? And who gives the least support?

For the sake of content validation of the instrument, interviews were held with four women with breast cancer and thirteen relatives, who were not included in the study.

\section{Procedures}

After confirming the family members' participation in the research, individual interviews were held on the date and time convenient for each. Data were collected in 2007 and started after approval by the Internal Review Board at EERP-USP, the subjects' acceptance to participate and the signing of the free and informed consent term.

All interviews were used, recorded and later transcribed, with the participants' permission.

For data organization and analysis, reports were categorized through thematic content analysis(8). Hence, the researchers attempted to identify contents in the relatives' statements that were related with the dimensions of the family dynamics model(7). For this cutting and extraction process, a map was created, whose excerpts were placed in the spaces related to the dimensions of the family dynamics model according to the participant's gender and family bond.

To guarantee greater reliability and validity in the content identification process, related to the dimensions of the family dynamics model, contents were submitted 
to construct validation by three experts, including one researchers experienced in the area and two Ph.D. students specialized in care to women's health and their families(9).

Experts participated in a presentation about the concepts of the theoretical model's dimensions and a set of excerpts from the interviews. They were then asked to classify them according to the model dimensions. After these procedures, agreement among the experts and the researchers was verified. In case of disagreement between the authors' and more than one expert's classification, the excerpt was discarded from the analysis process.

The excerpts from the thematic units that represented the dimensions of the family dynamics model were then grouped according to the participants' gender (male, female), without ignoring each member's family bond. Participants were identified with letters to identify kinship and gender: son (Fo), daughter (Fa), husband (Ma), aunt ( $\mathrm{Ta})$, niece ( $\mathrm{Sa}$ ) and numbers that identified which family $(F)$ they belonged to.

\section{Results and discussion}

Participants' age range in this research varied between 18 and 85 years, with women's ages ranging from 19 to 85 years and men's from 18 to 62 years.

The contents related to family dynamics that were most mentioned by the male and female relatives under analysis refer to the processes of identity and adaptation to changes, as shown in Table 2. It could also be identified that a large part of both genders identified the most positive aspects of these processes.

Table 2 - Processes and dimensions of family functioning according to male and female relatives' perceptions and family bond

\begin{tabular}{|c|c|c|c|c|c|c|}
\hline \multirow{2}{*}{ Processes } & \multirow{2}{*}{ Dimensions } & \multicolumn{2}{|c|}{ Male gender $n=12$} & \multicolumn{2}{|c|}{ Female gender $n=11$} & \multirow{2}{*}{ Total } \\
\hline & & Husband & Son & Daughter & Others & \\
\hline \multirow[t]{4}{*}{ Identity } & Individuation & 4 & 4 & 8 & 0 & 16 \\
\hline & Enmeshment & 1 & 0 & 0 & 0 & 1 \\
\hline & Mutuality & 6 & 5 & 9 & 1 & 21 \\
\hline & Isolation & 5 & 4 & 6 & 2 & 17 \\
\hline \multirow[t]{4}{*}{ Adaptation to changes } & Flexibility & 4 & 3 & 7 & 0 & 14 \\
\hline & Rigidity & 3 & 0 & 0 & 1 & 4 \\
\hline & Stability & 5 & 4 & 9 & 1 & 19 \\
\hline & Disorganization & 4 & 3 & 3 & 0 & 10 \\
\hline \multirow[t]{2}{*}{ Information } & Clear commun. & 4 & 3 & 5 & 0 & 12 \\
\hline & Distorted commun. & 4 & 1 & 4 & 2 & 11 \\
\hline \multirow[t]{4}{*}{ Role structure } & Role reciproc. & 4 & 2 & 4 & 0 & 10 \\
\hline & Role conflict & 1 & 0 & 1 & 0 & 2 \\
\hline & Clear generational boundaries & 0 & 0 & 0 & 0 & 0 \\
\hline & Diffuse boundaries & 0 & 0 & 3 & 0 & 0 \\
\hline
\end{tabular}

It should be highlighted that both genders revealed strongly similar perceptions on the positive aspects of the family identity and adaptation to change processes. In their statements, relatives from both genders evidences how their family gets organized and the extent to which each member got mobilized in view of the difficulties in daily family life.

As individuals, they talked about feelings, referring to the family members' suffering due to their mother/ partner's disease. Sons and daughters demonstrated that they felt like people who tried out their personal identities in family relationships and, in view of problems, assumed a problem-coping position, attempting to help, just like the other members of the family unit.
In our family, there is not somebody who gives less support, there is a sentence I like a lot: you do not give more of what you can offer, but everyone has something to offer, each person in his own way. I don't believe there is someone more complete to support in a single way (Fo-F2).

My other brothers did not help me because one is not at home, one studies in another city and the others are married, but they suffer a lot too, but I am the one who most sees everything (Fa-F7).

In the 20th century, the family was mainly characterized by the construction of a group logic centered on love and affection. That family was a group, regulated by love, in which adults were at the service of the group and mainly of the children. Man 
should go to work and woman should stay at home to make it pleasant inside. Nowadays, although the family still maintains some of its old characteristics, it differs from the past by the greater weight attributed to the "individuation" process. The central element is no longer the joined group, but its component members. Thus, the family turns into a private space at the service of individuals ${ }^{(10)}$.

Reflections about the contents of the statements identified as individuation and mutuality, presented by the male gender, specifically by the partners, reveal that the meaning of conjugality is related to the structure of conducts and attitudes in the family context.

I help myself in daily life with regard to her breast cancer. I never grow weary of saying that one of the best things I have done in my life was to get married, I found the right partner (Ma-F5).

There is no choice, are you going to sit inside a trough of holy water and is it going to get better? There is no solution, what do we have to do? You have to get the surgery, you have to remove it, so go and take care of that and we start to deal with the new situation. I am her husband and I have to help her (Ma F4).

Conjugality occurs for a set of individuals, at a given moment in one's personal trajectory, and is ideologically marked in a distinguished way, according to one's existential and gender conditions. For the male gender, strongly expressed by the partners under analysis, the production of meanings and personal identity in their family structure was constructed through the relation with their partner, across common life, and that is how they constructed a way of seeing the family world and themselves. And, in the situation of their wife's disease, for many of them, this demanded re-looking at the family dynamics ${ }^{(11)}$. It is through this relation constructed across marital life that husbands assumed their position in the family context after the breast cancer, giving signs of belonging to their family group and, thus, complying with important aspects of their social identity, as expressed below by one of the sons.

My father called me and said: son, Carmem is going to need us a lot. I perceived that it was a call, like, you are going to be part of this whole band, we need people (Fo1-F2).

On the other hand, the attitudes characterized by mutually and signs of individuation identified by the female gender, especially with regard to aspects of the daughter-mother relation, seem to be related to the morbid heritage ${ }^{(12)}$, as breast cancer is related to genetic factors.
I got quite frightened because they say that cancer is hereditary and I am 37 already. I changed my behavior, I try to take all breast exams, mammography, diagnostic imaging every year, I try to take more care of myself (Fa-F4).

That particularity entailed emotional proximity between mother and daughter, a sense of autonomy and personal responsibility for both women's health.

Everyone paid more attention, started to pay more notice, we are kind of more careful than we were before, more loving, we attempt to be nearer, not leave her alone, I am her daughter, I try to spend most of the time with her (Fa-F1).

Moreover, it is perceived that, for the female gender, family relations become marked by consistency, responsibility and security in view of the new reality in the family environment.

We got more united than we used to be, and we started to value life more, I started to give more value to life and the presence of my mother, I don't know, it's as if the daughter feels sorry more (Fa-F7).

My mother started to trust me more, I used to take care of lunch, of the house, I bathed her and did wound dressing, then she felt good (Fa-F9).

In this research, in the male gender, however, unshared identities were found, as shown by negative signs in family functioning, characterized by signs of isolation among its members, including their own isolation.

My older brother gives less support. He works, has a girlfriend, he spends little time here, he is kind of disconnected, does not try to get involved in family issues. He is more absent (Fa-F1).

There is nothing I can do for her, because I did not participate in the interpretation of the diagnosis, I didn't understand. Rarely, sometimes I took her to the physical therapist, or anything else. Intimate talks were more common with my sisters, as I am a man I only found out superficially (Fo-F5).

Identity sharing in family life gives form to the family's standards and ideals, to lines of authority, sexual differentiation, work division and attitudes in children's education.

Female relatives (daughter and sister) were highlighted, by themselves and other family members, as important elements for support and, consequently, they showed they were overloaded because they took charge of housework.

I perceive that I give support, I think that's because I am a daughter, I always attempt to be near her in all senses and do everything together with her. I think I am one of the persons who support her most because I am a woman. I practically took the lead in all this (Fa-F1). 
The gender role comprises the set of standards society and culture set for female or male behavior, so that people's feelings, behaviors, attitudes and games are determined by this identification(6).

A study ${ }^{(13)}$ among daughters of women with breast cancer showed that they experience intense emotions of shock, panic and exhaustion in view of the disease experience. Those findings suggest a hardly distinctive relation among these family members, with a certain symbiosis among them.

On the other hand, the gender role turns into a very influential social fact, so that the division between what is female and male work is seen as "natural". Men are responsible for the public, the power, setting guidelines and goals, directing and commanding high functions in functional hierarchies, while women are responsible for the children, for structuring the home, taking care of the elderly and everything else related to the domestic sphere(6).

These study findings reveal that, to maintain family stability, the female gender elements/daughters modified their routines to guarantee their mother's and, directly, their family's wellbeing.

I moved to another house and city, I brought my husband and son with me just to stay with my mother, things totally changed at home and at my mother's house, I'm her daughter and I want to take care of her (Fa-F9).

Family stability is a product of complex and interdependent processes, among which the continuity of identities over time, the control of conflicts in the family unit, the ability to change, to learn, to play new roles, to achieve a higher stage of development and, finally, the complementariness of relations in family roles stand out ${ }^{(13)}$.

Today we already talk, we make jokes because, at that time, we didn't make a lot of jokes about the disease, so today we already talk and make jokes, it happens often that we see her prosthesis and say, look at that breast jumping there. We are able to make that kind of jokes, I perceive that it's something that was overcome (Fa-F4).

The family's balanced functioning is maintained through multiple mental processes, including perception, memory, association, judgment and emotional control, coordinated by putting in practice the family constellation's mastering strategies and specific defenses. Stability is a characteristic of living systems and is guaranteed by regulation and control mechanisms, such as family rules for example. Both genders' statements evidenced that achieving family stability was conditioned by adaptive changes in family standards after the breast cancer, which strongly depended on the home's internal organization.

Nowadays, it has already become something daily, we have created a habit inside our home, our own lifestyle, the fact that one is there for the other (Fo-F2.).

I do everything I can for a home in harmony (Fa-F1).

These study findings, however, show that some negative aspects were present in the adaptation processes to changes inside the family, which were especially identified by the female gender. Signs of emotional disorganization were identified, as presented in the statements below.

I work, smoke, I drink beer to forget, when you drink beer, with so much popping up in our head you even forget, at least you relax a little and forget about your wife's problem (Ma-F3).

Her son, my disconnected brother, he's more concerned with his girlfriend and goes out (Fo-F1).

A research shows ${ }^{(14)}$ that caregivers experience an adverse influence on their work, and frequently lose work time to attend to their sick relative's demands.

I had an emotional problem, at work, I work as a typist, I was typing wrongly then my boss called me to know what was happening. At school I perceived that my performance got worse, my grades (Fo1-F1).

Stability and flexibility are opposed to rigidity and disorganization. Rigidity can make the family adopt standards that are not very adequate to their living conditions, while the lack of regularity in standards leads to chaos, making daily life unpredictable and disorganized(14-15). One husband's statement reveals this situation.

I help as I can, I can't change the way I am (Ma-F3).

In stabilization and change processes, communication among family members undergoes a decisive influence. Communication is considered the most important characteristic of good relationships, mainly because it allows family members to distinguish behaviors and increases the capacity to be understood, providing support(15).

$I$ and my wife used to talk about everything. Each detail, then everything became clear, we exactly talked about everything very clearly, without any restriction, without any fear (Ma-F2).

In families where strict boundaries predominate, members get distanced. Diffuse boundaries originate close and intimate relationships, although independence and autonomy are jeopardized. Adequate boundaries, on the other hand, permit proximity, affection and protection without generating enmeshment among members ${ }^{(15)}$. 
In this research, the male gender, represented by the partner, identifies indicators of distorted communication in family relationships in its own interaction.

Sometimes I think about doing things I want to do but you can't because it's going to cause problems, so there are many things you don't do. Sometimes I think about talking to my wife, but I don't, sometimes I just let it be and don't say anything, you really feel sorry (Ma-F3).

For the more expressive partners, it is easier to keep up dialogue and that favors the post-traumatic growth of couples that experience breast cancer ${ }^{(14)}$.

On the other hand, the certainty about the need for clear communication among family members, as male and female children and partners expressed, was the strategy they found to relieve tension and favor family interaction. It was the female gender, however, that most perceived signs of distorted communication among members, identifying some degree of family vulnerability for solving conflicts experienced in the family context. Likewise, women most strongly perceived the presence of diffuse or breached boundaries in family functioning. Some daughters perceived the father figure as someone who impaired family functioning.

My father gives less support, he doesn't ask what's wrong with her, if she's in pain or not, and we see that that makes her suffer a lot too (Fa-F7).

Family relations regulate the flow of emotions, facilitating some routes for emotional release while inhibiting others. The family structure controls the quality and quantity of emotional expression, as well as its sense.

\section{Final considerations}

Despite the limited number of families that were analyzed, these study findings evidence that the way family members perceive the family dynamics of women after breast cancer shows similarities in some dimensions and differences in others. It can be perceived that the male and female participants' affective bond with the woman with breast cancer is strengthened to the extent that social interactions are characterized by feelings of mutuality and signs of individuation, interiorized in the identity process of the family group.
Male members, especially partners, perceive that in their relation with their partner, the strengthening of identity processes in the family dynamics, through attitudes characterized by traits of individuation and mutuality, results in rewards and personal gratification. Thus, the male gender, especially sexual partners, constructed a way of seeing the family world and themselves as individual in a disease situation (breast cancer) that demands a re-look at the family dynamics.

Due to women's tasks and social roles inside the family, this research reveals that gender differences clearly attribute a participation profile to women that is characterized as more intense, more affective and more active in maintaining the family unit.

The mechanisms male and female family members use to seek balance in family functioning in view of the disease were information processes, choosing clear communication. That was one strategy that relieved tension and favored family interaction.

Women perceived the consequences of distorted communication and the establishment of diffuse boundaries in family relationships more. According to them, these revealed a certain degree of vulnerability and difficulty to solve conflicts experienced in the family context.

These study findings entail important implications for health services. The female population with breast cancer is a growing population group and, to the extent that its incidence and survival period are increasing, more families live with the difficulties of coping with the disease and its treatments. In this scenario, health services need to get organized in order to adequately manage demands, not only from women who survived breast cancer, but also from their relatives.

To achieve this, further research is recommended, with a view to examining the characteristics of family health determinants among women after breast cancer, focusing on male and female family members' participation in the woman's recovery process.

As nurses, the need for a multidisciplinary approach in family care is perceived, as families are constellations of individuals with gender differences, own opinions, viewpoints and highly significant positions in the family dynamics.

\section{References}

1. Kirsch SED, Bradt PA, Lewis FM. Making the most of the moment, When a child 'smother has breast cancer. Cancer Nurs. 2003; 26(1):47-54.

2. Martins CS, Ferriani MGC, Silva MAI, Zahr NR, Arone KMB, Roque
EMST. A dinâmica familiar na visão de pais e filhos envolvidos na violência doméstica contra crianças e adolescentes. Rev Latinoam Enfermagem. 2007 setembro-outubro; 15(5):889-94.

3. Cleoneide POP, Silva RM, Mamede MV, Fernandes AFC. 
Participação em grupo de apoio: experiência de mulheres com câncer de mama. Rev Latino-am Enfermagem. 2008 julhoagosto; $16(4): 733-8$

4. Wernet M. Enfermagem e família investindo no primeiro passo. Rev Bras Enferm. 2000 dezembro; 53(n.especial):87-9.

5. Bervian PI, Perlini NMOG. A família (con)vivendo com a mulher/mãe após a mastectomia. Rev Bras Cancerol. 2006 agosto; 52(2):121-8.

6. Villela WV, Arilha M. Sexualidade, gênero e direitos sexuais e reprodutivos. In: Berquó $\mathrm{E}$, organizadora. Sexo e vida: panorama da saúde reprodutiva no Brasil. Campinas: Ed. Unicamp; 2003. p. $95-150$.

7. Barnhill L. Healthy family systems. Family Coordinator 1979 ; 28:94-100.

(8) Bardin L. Análise de conteúdo. Lisboa: Edições 70; 1977. 9. Cozby PC. Métodos de pesquisa em ciências do comportamento. São Paulo (SP): Atlas; 2003.
10. Singly FO. Nascimento do "indivíduo individualizado" e seus efeitos na vida conjugal e familiar. In: Peixoto $C E$, organizadoras. Família e individualização. Rio de Janeiro (RJ): FGV; 2000. p.13-49. 11. Torres A. individualização no feminino, o casamento e o amor. In: Peixoto CE, organizadoras. Família e individualização. Rio de Janeiro (RJ): FGV; 2000. p. 135-56.

12. Volich RM. Câncer de mama, entrelinhas, entranhas: Perspectivas Psicanalaticas. Bol Novidades Pulsional. 1998 107:16-25.

13. Raveis $\mathrm{VH}$, Pretter S. Existential plight of adult daughters following their mother's breast cancer diagnosis. Psycho-Oncol. 2005; 14(2):49-60.

14. Grunfeld E. Family caregiver burden: results of a longitudinal study of breast cancer patients and their principal caregivers. Can Med Assoc J 2004; 170(12):1795-801.

15. Nichols MP, Schwartz RC. Terapia familiar: conceitos e métodos. Porto Alegre (RS): Artmed; 1998. 